\title{
Tokak Yerel Arpa Çeşidi İçinden Seçilen Safhatların Bazı Gıda, Yem ve Tarımsal Özellikler Bakımından Varyasyonları
}

\author{
Fatma Ruveyda ALKAN ${ }^{1}$ \\ Nejdet KANDEMIR ${ }^{2}$ \\ ${ }^{1}$ Tarla Bitkileri Merkez Araştırma Enstitüsü Müdürlüğü-Ankara \\ ${ }^{2}$ Gaziosmanpaşa Üniversitesi, Ziraat Fakültesi Tarla Bitkileri Bölümü-Tokat \\ Sorumlu yazar e-mail (Corresponding author e-mail): fatmaruveyda.alkan@gthb.gov.tr \\ Geliş Tarihi (Received): 20.10.2015 Kabul Tarihi (Accepted): 15.12.2015
}

Öz

Bu çalışmada Tokak yerel arpa çeşidi içinden (PI 470281) moleküler markörlerle seçilen 25 hat Tokat Kazova şartlarında tarla koşullarında incelenmiştir. Araştırmada referans olarak Kanada'nın en önemli maltık arpa çeşidi Harrington ve Türkiye'de yaygın şekilde tarımı yapılan bir maltlık arpa çeşidi olan Tokak 157/37 kullanılmıştır. Yapılan çalışmada PI 470281 hatları agronomik özellikler yanında (Çiçeklenme süresi, olgunlaşma süresi, bitki boyu, yatma oranı, başakta tane sayısı, başak boyu, 1000 tane ağırlığı, hektolitre ağırığı, tane verimi, biyolojik verim, hasat indeksi), bazı yem kalite özellikleri (ham kül oranı, ham protein oranı, ADF, NDF) ve çeşitli mineral madde içerikleri (P, K, Ca, Mg, Fe, Cu, Mn, Zn) gibi gıda kalite özellikleri bakımından incelenmiştir. Değerlendirmeye alınan PI 470281 hatları agronomik, yem ve gıda kalite özelikleri yönüyle önemli varyasyonlar göstermiştir. Hatların büyük çoğunluğu Tokak 157/37'den daha yüksek Harrington'dan ise daha düşük tane verimine sahip olmuşlardır. Değerlendirmeye alınan hatlarda 1000 tane ağırığı yaklaşık 40-51 g, hektolitre ağılıkları ise 64-69 kg arasında değişmiştir. ADF, NDF oranları referans çeşitlerinden yüksek veya yakın değer göstermişlerdir. \%12-14 arasında değişen ham protein oranlarındaki farklılıklar da önemli bulunmuştur. PI 470281 hatları arasında mineral madde oranları bakımından da önemli varyasyonlar tespit edilmiştir. Hatların demir, bakır ve kalsiyum konsantrasyonları referans çeşitlerine yakın veya yüksek değer göstermiştir. Sonuç olarak, Tokak yerel çeşidinin yüksek genetik çeşitliliğe sahip olduğu, bu çeşit içinden geliştirilen safhatlarda, agronomik, yem ve gıda kalite özellikleri açısından ıslahta kullanılabilecekleri varyasyonun bulunduğu sonucuna ulaşıımıştır.

Anahtar Kelimeler: Mineral element içeriği, 1000 tane ağırlığı, asit deterjan lif, ham protein, ham kül.

\section{Variations in some Food, Feed and Agricultural Characteristics of Purelines Selected from Tokak Barley Landrace}

\begin{abstract}
In this study, twenty-five lines selected from Tokak (PI 470281) barley landrace using molecular markers were investigated in field studies under Tokat Kazova conditions in Turkey. Harrington, a malting barley variety of Canada, and Tokak 157/37, a commonly grown malting barley variety in Turkey, were used as reference. PI 470281 lines were investigated in terms of food and feed quality properties such as crude ash, crude protein, ADF, NDF contents, various mineral contents such as $\mathrm{P}, \mathrm{K}, \mathrm{Ca}, \mathrm{Mg}, \mathrm{Fe}, \mathrm{Cu}, \mathrm{Mn}, \mathrm{Zn}, \mathrm{Cr}$ and some agronomic traits such as days to flowering and maturity and plant height, number of seeds per head, spike length, 1000 seed weight, test weight, grain yield, biological yield and harvest index. PI 470281 lines investigated showed significant variations in terms of their agronomic, feed and food quality properties. Most of the lines had higher grain yields than Tokak 157/37 and lower than Harrington. 1000-seed weights and test weights for the lines investigated varied from 40 to $51 \mathrm{~g}$ and 64 to $69 \mathrm{~kg}$, respectively. Their ADF and NDF contents were higher than or similar to those of the reference cultivars. The crude protein contents varied from $12 \%$ to $14 \%$ and were significantly different among purelines. Significant variations were found among PI 470281 lines in terms of mineral contents. $\mathrm{Fe}, \mathrm{Cu}$, and $\mathrm{Ca}$ concentrations of pure lines were higher than or similar to those of the reference values. As a result, Tokak barley landrace has high genetic variations, and purelines developed from this variety has variations that could be used in breeding for agronomic, feed, and food quality properties.
\end{abstract}

Keywords: : Mineral element content, 1000-seed weight, acid detergent fiber, crude protein, crude ash. 


\section{Giriş}

A rpa hayvan yemi olarak, bira yapımında ve insan beslenmesinde kullanılmaktadır (Grando ve Macpherson 2005). Bugün dünyada ekimi yapılan arpanın \%65'i hayvan yemi olarak, \%33'ü maltlık olarak bira ve viski yapımında, \%2'si de insan besini olarak gıda endüstrisinde kullanılmaktadır. Ülkemizde ise tüketimin \%90'ı hayvan yemi olarak, kalan kısmı maltlık olarak bira sanayinde ve gıda endüstrisinde kullanılmaktadır. Gıda endüstrisinde kullanılan oran çok düşük olsa da giderek artmaktadır (Anonim 2010). Tanesindeki yüksek sindirilebilir lif oranı ve yüksek $\beta$-glukan oranından dolayı arpa insan beslenmesinde önem kazanmaya başlamıştır. Bazı ülkelerde arpa unu, buğday unu içerisinde katkı maddesi olarak kullanılmaktadır (Sipahi ve ark. 2010).

Arpa tanesinin çeşitli mineral maddelerce zengin olduğu ve bu maddelerin hayvanlar açısından da hayati fonksiyonlara sahip oldukları öteden beri bilinmekte olup, hayvan beslemede yaygın biçimde kullanılmaktadır (Sönmez ve Yılmaz. 2000). Arpa tanesi, bünyesinde bulundurduğu yaklaşık $\% 67$ karbonhidrat, \%10 protein, \%2 yağ, \%5 selüloz ve kalsiyum, fosfor, potasyum gibi mineraller ile A vitamini, E vitamini ve $B$ vitamini içeriği ile hayvanların beslenmesinde önemli bir yere sahiptir. Hayvan beslenmesinde yoğun şekilde kullanılan arpa, ihtiva ettiği mineral ve vitaminler ile değerli bir yem konumundadır. Arpanın tane kompozisyonu konusunda birçok çalışma yürütülmüştür (Guo ve ark. 2003; AghaeeSarbarzeh ve ark., 2005; Bekele ve ark. 2005). Genetik farklılıkların arpanın kimyasal içeriğine etki ettiği ve farklı genotipler arasında farklı oranda mineral madde içeriğinin olduğu daha önce yapılan çalışmalarda bildirilmiştir (Guo ve ark. 2003).

Kültür bitkilerinin verim ve kalite özellikleri bitki ıslahı yoluyla iyileştirilirler. Yani genetik varyasyonlar bitki ıslahının temelini oluşturmaktadır. Bazı genetik kaynaklar bitki ıslah programlarında fazlaca kullanılmışlardır ve bu nedenle bazı kültür bitkilerinin gen tabanları oldukça daralmıştır. Bitki ıslahının genetik tabanını geliştirmek için yabani akraba türler ve yerel çeşitler büyük avantajlar sunarlar. Bu noktada kalite özelliklerinin geliştirilmesinde yerel çeşitler avantajııdır, çünkü istenen gen yanında gelen hedeflenmemiş genler yerel çeşitlerden geldiğinde yabani türlere nazaran daha az olumsuz etkilere sahiptirler. Yerel çeşitler morfolojik olarak benzer, fakat genetik olarak farklı popülasyonlardır (Harlan 1975). Gen bankalarında muhafaza edilen yerel çeşitlerdeki genetik varyasyonun yaklaşık \%5060'ı yerel çeşitler içinde bulunmaktadır (Parzies ve ark. 2000). Ancak yerel çeşitlerdeki genetik varyasyonların bitki ıslahında kullanılabilmeleri için öncelikle genetik varyasyon seviyelerinin belirlenmesi gerekir. Arpanın orijin merkezlerinden birisi olan Türkiye, arpa yerel çeşitleri konusundaki araştırmalar arpada verim ve kalite ile ilgili özelliklerin ıslahında yeni alleller bulunması konusunda çok faydalı olabilirler. Yerel çeşitlerin içinde yüksek düzeyde genetik varyasyon bulunmaktadır. (Parzies ve ark. 2000; Jaradat ve ark. 2004). Bu genetik varyasyonun bitki ıslahında kullanılması için belirlenmesi ve karakterize edilmesi gerekmektedir (Alemayehu ve Parlevliet 1997). Tarımı yapılan ticari çeşitlerin aksine yerel çeşitler yoğun seleksiyonlara maruz kalmamışlardır ve bu nedenle tane kalitesi gibi bugüne kadar ıslaha konu olmayan karakterler için önemli varyasyonlar barındırabilirler (Kandemir ve ark. 2010). Birçok gelişmekte olan ülkede yerel çeşitlerin tarımı, düşük verim potansiyeli ve hastalıklara olan duyarlılıklarından dolayı yapılmamaktadır. Ancak düşük girdili tarım yapılan şartlarda yerel çeşitler yabancı orijinli çeşitlerden daha yüksek verim verebilirler (Ceccarelli ve ark. 1987). Yerel çeşitler safhat seleksiyonu yoluyla verimi artırmak için kullanılabilirler. Ayrıca özellikle olumsuz çevre şartlarına dirençlilik araştırmalarında ve bitki ıslahında ebeveyn olarak kullanılma potansiyelleri bulunmaktadır (Ceccarelli ve Grando 2000).

$\mathrm{Bu}$ çalışmada Tokak yerel arpa çeşidinden DNA markörleri kullanılarak seçilmiş olan farklı hatlar tarımsal özellikleri bakımından incelenerek aralarında kalite ıslahında kullanılabilecek önemli farklılıkların olup olmadığı araştırılmıştır.

\section{Materyal ve Yöntem}

Bu araştırma 2011 vejetasyon döneminde Gaziosmanpaşa Üniversitesi Ziraat Fakültesi Tarla bitkileri Bölümü deneme alanında yazlık olarak yürütülmüştür. Deneme materyali olarak Tokak yerel arpa çeşidinden (PI 470281) moleküler markörlerle genetik çeşitliliğine göre seçilen 25 hat kullanıımıştır. Araştırmada kontrol çeşidi olarak da dünyada iyi tanınan bir maltlık 
arpa çeşidi olan Harrington ile Türkiye'de yaygın şekilde tarımı yapılan Tokak 157/37 kullanılmıştır. Deneme tesadüf blokları deneme desenine göre 3 tekerrürlü olarak yürütülmüştür. Bitkiler $20 \mathrm{~cm}$ aralıklı, $3 \mathrm{~m}$ uzunluğundaki sıralarda, 5 sıradan oluşan parsellerde yetiştirilmiş olup ekim miktarı $20 \mathrm{~kg} / \mathrm{da}$ olarak ayarlanmıştır. Parseller arasına hatların yatmasının birbirini etkilememesi için birer sıra yatmaya dayanıklı bir buğday çeşidi ekilmiştir. Parsellere triple süperfosfat ve amonyum nitrat halinde dekara $7,5 \mathrm{~kg} \mathrm{P}_{2} \mathrm{O}_{5}$ ve $8 \mathrm{~kg} \mathrm{~N}$ hesabıyla gübre uygulaması yapılmıştır (Kandemir 2004). Fosforlu gübrenin tamamı ve azotlu gübrenin yarısı ekimle birlikte, azotlu gübrenin diğer yarısı sapa kalkma dönemi öncesi verilmiştir. Bitkilerin hasadı taneler sarı olum dönemine geldiğinde elle yapılmış, gevşek demet halinde kurutulduktan sonra makineyle harmanlanmıştır. 2011 yılına ait deneme yerinin iklim özellikleri ise Şubat-Temmuz ayı sıcaklık ortalaması $13,6^{\circ} \mathrm{C}$, bu aylar için ortalama yağış miktarı ise $337 \mathrm{~mm}$ olarak belirlenmiştir (Anonim 2011).

Bitki boyu (cm): Her parselden tesadüfen seçilen 20 bitkinin başak ucu (kılçık hariç) ile toprak yüzeyi arasındaki dikey uzaklık ölçülerek belirlenmiştir (Kandemir ve ark. 2000).

Yatma oranı (\%): Her parselde yatan bitkilerin oranı gözleme dayalı \% olarak belirlenmiştir (Kandemir ve ark. 2000).

Çiçeklenme süresi (gün): Çıkış tarihinden bitkilerin \%50'sinin kılçıklarını veya başağını çıkardığı tarihe kadar geçen süre gün olarak hesaplanarak belirlenmiştir (Kandemir ve ark. 2000).

Başakta tane sayısı (adet/başak): Her parselden rastgele seçilen 20 başaktaki tane sayısı sayılarak belirlenmiştir (Turan 2008).

Başak uzunluğu (cm): Her parselden hasat öncesi alınan 20'şer başak örneği başak alt boğumundan kılçıklar hariç başakta en üst başakçık ucuna kadar olan uzunluk $\mathrm{cm}$ olarak ölçülüp, ortalaması alınarak hesaplanmıştır (Turan 2008).

Biyolojik verim (kg/da): Hasat edilen parsel ürünleri, 5 gün süreyle deneme alanında kurumaya bırakılmış ve daha sonra bu ürünler tartılarak kg/da'a çevrilmiştir (Akdeniz ve ark. 2004).

Tane verimi (kg/da): Parsellerdeki bitkiler harman edildikten sonra tane nemi \%8'e ayarlanmış, elde edilen tane ürünü tartılarak değerler kg/da'a çevrilerek hesaplanmıştır (Turan 2008).

1000 tane ağırlığı (g): Parseller harman edildikten ve kurutulduktan sonra dört adet 100 tane sayılmış ve ortalama ağırlıkları üzerinden 1000 tane ağırlığı belirlenmiştir (Kandemir ve ark. 2000).

Hektolitre ağırlığı (kg): Tohumlar kılçıklarından tamamen ayrıldıktan sonra 4 adet $250 \mathrm{ml}$ ölçüm yapılmış ve hektolitre ağırlıkları hesaplanmıştır.

Olgunlaşma süresi (gün): Olgunlaşma gün sayısı, ekimden bitki ve yaprakların tamamının sarardığı tarih dikkate alınarak belirlenmiştir (Öztürk ve ark. 2007).

Hasat indeksi (\%): Her parsele ait tane verimi o parsele ait biyolojik verime oranlanmış, daha sonra \% olarak hesaplanmıştır (Turan 2008).

Ham kül oranı (\%): Ham besin analizleri yapmak için laboratuar değirmeninde, öğütülerek hazırlanan örneklerden $1 \mathrm{~g}$ tartılmıştır. İçinde öğütülmüş arpa örneği bulunan krozeler $550{ }^{\circ} \mathrm{C}$ 'ye ayarlı yakma fırınına konularak 4-5 saat yakılmıştır. Bu sıcaklıkta kömürleşme olmayacak şekilde, kül açık griden beyaza değişen bir renge ulaşana kadar yakma fırınında tutulmuştur. Yaklaşık $100{ }^{\circ} \mathrm{C}$ ye soğutulduktan sonra krozeler desikatöre alınmış ve yeterince soğutulduktan sonra tartılmıştır.

Aşağıdaki formülde tartım sonuçları yerine koyularak \% ham kül oranı belirlenmiştir (Kutlu 2008).

$$
\% \text { Ham kül }=\frac{c-a}{b-a} \times 100
$$

a: kroze daras

b: kroze darası + numune

c: kroze darası + kül

Ham protein oranı (\%): Öğütülmüş arpa numunesi derişik $\mathrm{H}_{2} \mathrm{SO}_{4}$ ile yakılmak suretiyle arpada bulunan azotun önce amonyum sülfata sonra alkali (sodyum hidroksit) ile amonyağa dönüştürülerek, titrasyonla amonyaktaki azot miktarı hesaplanmıştır (Kutlu 2008).

$A=$ [Tit. Har. HCL- Kör. İçin harcanan $\mathrm{HCL}] \times 0,2 \times 1,4007$

$\mathrm{B}=\mathrm{A} /$ [Örnek (g) $\times$ Kuru Madde / 100 ]

Ham Protein Oranı (\%) = B×5,83 (Faktör: Arpa, çavdar, yulaf ve darıda) 
Asit deterjan lif (ADF) oranı (\%): Ancom F57 torbalarının üzerleri numaralandırılıp darası alındıktan sonra her birisinin içine $0,5 \mathrm{~g}$ öğütülmüş örnekler konulmuştur. Bir tane de kör için boş torba tartılmıştır. Ancom F57 torbaları üst kenara $4 \mathrm{~mm}$ uzaktan heat sealer aleti yardımıyla kapatılmıştır. Ancom F57 torbaları sallandığında içerisindeki arpa örnekleri düzenli olarak dağılması sağlanmıştır. Hazırlanan örnekler katlı torba rafının içerisine her gözde üç torba olacak şekilde yerleştirilmiştir. 24 adet örnek için 1900-2000 ml önceden hazırlanan ADF Solüsyonu (ADF çözeltisi içeriği; Ankom Acid Detergent Dry powder "CTAB" - Ankom FAD20C, $1 \mathrm{~N} \mathrm{H}_{2} \mathrm{SO}_{4}$ ) ilave edilerek $100{ }^{\circ} \mathrm{C}$ 'de 60 dakika kaynatılmıştır. Kaynatma sonunda haznedeki çözelti boşaltılmış, 2 defa sıcak saf su 1 defada soğuk saf su ile yıkanan torbalar plastik taşıyıcıdan alınarak 3-5 dakika asetonla yıkanmıştır. Asetonla yıkama işleminden sonra torbalar önce ortam sıcaklığında yaklaşık 1 saat kadar, daha sonra da $105^{\circ} \mathrm{C}$ 'de 2-4 saat kurutulup tartılmış ve örneklerin\% ADF içerikleri hesaplanmıştır (Kutlu 2008).

Nötral deterjan lif (NDF) oranı (\%): Ancom F57 torbalarının üzerleri numaralandırılıp darası alındıktan sonra her birisinin içine $0,5 \mathrm{~g}$ öğütülmüş örnekler konulmuştur. Bir tane de kör için boş torba tartılmıştır. Ancom F57 torbaları sallandığında içerisindeki arpa örnekleri düzenli olarak dağılması sağlanmıştır. Hazırlanan örnekleri katı torba rafının içerisine her gözde üç Ancom F57 torbası olacak şekilde yerleştirilmiştir. 24 adet örnek için 2 It NDF çözeltisi (NDF çözeltisi içeriği; Ankom Neutral Detergent Dry powder - Ankom FND20C, Triethylene Glycol) ilave edilerek $100^{\circ} \mathrm{C}$ 'de 75 dakika kaynatılmıştır. Kaynatma sonunda haznedeki çözelti boşaltılmıştır. Daha sonra cihazın kapağı tamamen açılarak içerisine 80$90^{\circ} \mathrm{C}$ sıcaklığında $2000 \mathrm{ml}$ (katı torba rafının üzerini örtecek kadar) sıcak saf su ve $4 \mathrm{ml}$ alfa amilaz eklenmiştir. Zaman sayacı 5 dakikaya ayarlanmış ve süre bitiminde cihaz içerisindeki su tekrar boşaltılmıştır. Yukarıda yapılan sıcak $\mathrm{su}+4 \mathrm{ml}$ alfa amilaz ile kaynatma-yıkama işlemi 1 kez daha yapılmış ve böylece toplam 2 kez tekrarlanmıştır. Cihaza son olarak katı torba rafının kolay alınmasını sağlamak amacı ile $2000 \mathrm{ml}$ soğuk saf su ilave edilmiştir. Saf su tahliye edildikten sonra katlı torba rafı çıkartılmıştır. Torbalar $250 \mathrm{ml}$ 'lik behere konulmuş ve üzerlerini kaplayacak şekilde aseton eklenmiştir. Beherde torbalar 3- 5 dakika kaldıktan sonra çıkartılmış ve asetonun uzaklaşması için yavaşça sıkılmıştır. Daha sonra torbalar önce ortam sıcaklığında yaklaşık 1 saat kadar, daha sonra da $105^{\circ} \mathrm{C}$ 'de $2-4$ saat kurutulup tartılmış ve \% NDF içerikleri hesaplanmıştır (Kutlu 2008).

$\%$ ADF ve $\%$ NDF ;

Örnek (g) $\times$ Kuru Madde/100= A

Örnek+Torba (g)- [Torba (g) x Kör ağırı̆̆ı] =B

100 x B / A formülüyle hesaplanmıştır.

Kör ağırlığı: Boş torbanın kurutulduktan sonraki ağırlığı/darası.

\section{Verilerin Değerlendirilmesi}

Elde edilen bulgular denemenin kuruluş yöntemi olan Tesadüf Blokları Deneme Desenine göre varyans analizlerine tabi tutulup, sonuçlar MSTAT istatistiksel analiz programı kullanılmıştır. Yapılan varyans analizi soncu hatlar arasındaki farklılığın önem düzeyi ( $\% 5$, $\%$ 1) $\mathrm{F}$ testine göre belirlenmiş, hatlara ait ortalamaların farklııı gruplandırması Duncan testine göre yapılmıştır (Freed ve Eisensmith 1986).

\section{Bulgular ve Tartışma}

Çiçeklenme süresi, Olgunlaşma süresi, Bitki boyu ve Yatma oranı

Çiçeklenme süresi bakımından değerlendirmeye alınan PI 470281 hatları arasında 217 numaralı hat 80,3 gün ile diğer hatlardan belirgin derecede daha geç çiçeklenmiş ve kontrol çeşitleriyle aynı değeri göstermiştir (Çizelge 1). En erken çiçeklenme ise 51 ve 215 numaralı hatlarda 75,0 gün olarak gerçekleşmiştir. Akıncı ve Yıldırım (2009) yerel çeşitler içerisinde çiçeklenme süresinde 15 güne varan farklılıklar gözlemlemişlerdir. Yine Assefa (2005) yaptığı çalışmasında 62 yerel arpa hattı içinden seçilen 8 hattın çiçeklenme süresinin 79,1-92,0 gün arasında değiştiğini bildirmiştir.

En uzun olgunlaşma süresi 217 numaralı hatta 130,3 gün olarak tespit edilmiş ve bu olgunlaşma süresi ile 217 numaralı hat diğer hatlardan tamamen farklı olgunlaşma süresine sahip olmuştur (Çizelge 1). En kısa olgunlaşma süresi 221 numaralı hatta 124,7 gün olarak belirlenmiştir. Yapılan bir çalışmada 62 yerel arpa hattı içinden seçilen 8 hattın olgunlaşma sürelerinin 122-141 gün arasında değiştiği ortaya konulmuştur (Assefa 2005).

Bitki boyu açısından hatlar değerlendirildiğinde en kısa boylu 67 numaralı hat olmuş ve bu hattı 
$94,5 \mathrm{~cm}$ ile 62 numaralı ve $94,6 \mathrm{~cm}$ ile 215 numaralı hat izlemiştir (Çizelge 1). Kontrol çeşitlerinden Harrington 109,1 cm, Tokak 157/37 115,4 cm boylanmıştır (Çizelge 1). Weltzien ve Fischbeck (1990) Suriye ve Ürdün'den toplam sekiz adet yerel çeşit popülasyonlarından seçilen homozigot hatları bitki boyu bakımından değerlendirmiş ve kontrol çeşitleri ile karşılaştırıldığında hatların büyük çoğunluğunun kontrol çeşitlerinden yüksek boylu olduğunu bildirmişlerdir.

Yatma oranları bakımından hatlar incelendiğinde, yatma oranı $\% 68,07-90,00$ arasında değişiklik göstermiştir (Çizelge 1) Bazı hatların yüksek yatma oranına sahipken yüksek verim vermesi yatma açısı ile değil, yatmanın zamanlaması ile ilgilidir. Bazı hatlar henüz başaklanmaya bile ulaşmadan yatarken diğerleri tane dolumunun ileri aşamalarında yatmıştır. Farklılık bundan kaynaklanmıştır. Referans çeşitlerinden olan Harrington $\% 42,78$ ile en düşük yatma oranına sahip olurken, Tokak $157 / 37$ ise $\% 83,85$ ile yüksek yatma oranına sahip olmuştur. Özellikle yıllık yağışın $400 \mathrm{~mm}$ üzerinde olduğu yerlerde ve yıllarda arpada ciddi verim kayıpları yaşanmaktadır

Çizelge 1. PI 470281 hatları ile Tokak 157/37 ve Harrington çeşitlerinin çiçeklenme süresi, olgunlaşma süresi, bitki boyu ve yatma oranına ait değerler

Table 1. Days to flowering, maturity, plant height and lodging of PI 470281 lines, Tokak 157/37 and Harrington varieties

\begin{tabular}{|c|c|c|c|c|c|c|}
\hline & $\begin{array}{l}\text { Çiçeklenme } \\
\text { süresi (gün)** }\end{array}$ & \multicolumn{2}{|c|}{$\begin{array}{l}\text { Olgunlaşma } \\
\text { süresi (gün)** }\end{array}$} & \multicolumn{2}{|c|}{$\begin{array}{l}\text { Bitki boyu } \\
(\mathrm{cm})^{\star *}\end{array}$} & \multirow{2}{*}{$\begin{array}{c}\text { Yatma oranı } \\
(\%)^{*} \\
42,78 \mathrm{~B}\end{array}$} \\
\hline Harrington & $80,3 \mathrm{~A}$ & 132,7 & $A$ & 109,1 & $A$ & \\
\hline Tokak 157/37 & $80,3 \mathrm{~A}$ & 130,3 & $B$ & 115,4 & $A$ & $83,85 \mathrm{~A}$ \\
\hline 40 & 75,3 EF & 127,7 & C & 96,2 & $\mathrm{BC}$ & $72,29 A$ \\
\hline 44 & $76,0 \mathrm{EF}$ & 125,7 & EFG & 99,8 & $\mathrm{BC}$ & $90,00 \mathrm{~A}$ \\
\hline 46 & $77,7 \mathrm{CD}$ & 127,0 & CDE & 97,9 & $\mathrm{BC}$ & $76,92 \mathrm{~A}$ \\
\hline 50 & $75,7 \mathrm{EF}$ & 125,7 & $D-G$ & 99,5 & $\mathrm{BC}$ & $90,00 \mathrm{~A}$ \\
\hline 51 & $75,0 \mathrm{~F}$ & 126,0 & $C-G$ & 96,6 & $\mathrm{BC}$ & $90,00 \mathrm{~A}$ \\
\hline 53 & 79,0 B & 127,7 & C & 101,1 & $\mathrm{~B}$ & $76,92 \mathrm{~A}$ \\
\hline 56 & $76,0 \mathrm{EF}$ & 125,7 & $D-G$ & 98,8 & $\mathrm{BC}$ & $68,07 \mathrm{~A}$ \\
\hline 59 & $75,3 \mathrm{EF}$ & 125,3 & EFG & 96,0 & $\mathrm{BC}$ & $76,92 \mathrm{~A}$ \\
\hline 61 & $76,0 \mathrm{EF}$ & 126,0 & $D-G$ & 96,3 & $\mathrm{BC}$ & $90,00 \mathrm{~A}$ \\
\hline 62 & $75,3 \mathrm{EF}$ & 125,7 & $D-G$ & 94,5 & $\mathrm{BC}$ & $90,00 \mathrm{~A}$ \\
\hline 64 & $78,0 \mathrm{BC}$ & 127,3 & CD & 97,4 & $\mathrm{BC}$ & $78,93 \mathrm{~A}$ \\
\hline 67 & 76,3 DEF & 125,7 & $D-G$ & 93,0 & $\mathrm{C}$ & $90,00 \mathrm{~A}$ \\
\hline 201 & $76,0 \mathrm{EF}$ & 126,3 & C-G & 98,8 & $\mathrm{BC}$ & $68,07 \mathrm{~A}$ \\
\hline 206 & $75,3 \mathrm{EF}$ & 126,7 & $\mathrm{C}-\mathrm{F}$ & 98,3 & $\mathrm{BC}$ & $70,08 \mathrm{~A}$ \\
\hline 207 & $76,7 \mathrm{DE}$ & 126,3 & C-G & 99,1 & $\mathrm{BC}$ & $75,00 \mathrm{~A}$ \\
\hline 208 & 76,3 DEF & 126,3 & $C-G$ & 101,6 & $B$ & $90,00 \mathrm{~A}$ \\
\hline 210 & $75,7 \mathrm{EF}$ & 125,3 & EFG & 97,3 & $\mathrm{BC}$ & $85,69 \mathrm{~A}$ \\
\hline 212 & $75,7 \mathrm{EF}$ & 125,0 & $\mathrm{FG}$ & 97,7 & $\mathrm{BC}$ & $70,69 \mathrm{~A}$ \\
\hline 213 & 76,7 DE & 127,0 & CDE & 97,5 & $\mathrm{BC}$ & $90,00 \mathrm{~A}$ \\
\hline 215 & $75,0 \mathrm{~F}$ & 125,0 & $F G$ & 94,6 & $\mathrm{BC}$ & $76,92 \mathrm{~A}$ \\
\hline 217 & $80,3 \mathrm{~A}$ & 130,3 & B & 108,8 & A & $68,07 \mathrm{~A}$ \\
\hline 221 & $75,3 \mathrm{EF}$ & 124,7 & $\mathrm{G}$ & 100,3 & $\mathrm{BC}$ & $90,00 \mathrm{~A}$ \\
\hline 224 & $76,3 \mathrm{EF}$ & 126,3 & $C-G$ & 98,9 & $\mathrm{BC}$ & $90,00 \mathrm{~A}$ \\
\hline 227 & 76,0 EF & 125,7 & D-G & 97,7 & $\mathrm{BC}$ & $76,92 \mathrm{~A}$ \\
\hline 228 & 76,3 DEF & 126,0 & D-G & 97,2 & $\mathrm{BC}$ & $90,00 \mathrm{~A}$ \\
\hline
\end{tabular}

${ }^{*}$ Aynı harf grubuna giren ortalamalar arasında Duncan testine göre $\% 5$ seviyesinde önemli farklılıklar yoktur.

${ }^{* *}$ Aynı harf grubuna giren ortalamalar arasında Duncan testine göre \%1 seviyesinde önemli farklılıklar yoktur.

*, ${ }^{* *}$ There is no significant difference between the groups with the same letters at $5 \%$ and $1 \%$ level, respectively. 
(Akar ve ark. 1999). Buna göre, yatma Tokat ekolojik şartlarında arpa çeşitlerinin seçiminde dikkate alınması gereken en önemli özelliklerden birisidir. Arpada bitki boyu yatmayı etkileyen en önemli bitkisel özelliktir (Anderson ve ark. 1985). Kandemir (2004) $100 \mathrm{~cm}$ üzerinde olan arpaların yattığını bildirmiştir. Değerlendirilmeye alınan hatların bitki boyu 100 cm'nin altında olmasına rağmen yatma görülmüştür. Bu da göstermektedir ki yatma oranı yerel çeşitlerde yüksektir. Bu nedenle yatma özelliği yerel çeşit hatlarının doğrudan çeşit olarak kullanımını sınırlayacak durumdadır.

Başakta tane sayısı, Başak boyu, 1000 tane ağırlığı, Hektolitre ağırığı

Arpada verim başakta tane sayısı, birim alanda başak sayısı ve 1000 tane ağırlığı karakterlerinin etkileşimi sonucu ortaya çıkmaktadır. Başakta tane sayısı bakımından incelenen hatlar arasında en yüksek tane sayısı 61 numaralı hatta 23,30 adet ile belirlenmiştir (Çizelge 2). En az başakta tane sayısı 51 numaralı hatta 20,40 adet ile belirlenmiştir. Hatların kendi aralarında istatistiksel olarak farklılık bulunmayıp başakta bulunan tane sayısı 20,40 adet ile 23,30 adet arasında değişmiştir. Hatlar kendi aralarında ve Tokak 157/37 (21,80 adet) çeşidi ile aynı grupta yer alırken, Harrington (27,67 adet) çeşidi ile farklı istatistiki grupta yer almıştır. Jaradat ve ark. (2004) Umman arpa yerel çeşidinde başakta tane sayısı bakımından önemli varyasyonlar belirlemişlerdir. Başakta tane sayısı bakımından kontrol çeşitlerinden elde edilen değerler daha önce farklı ekolojik koşullarda (Akdeniz ve ark. 2004; Kaydan ve Yağmur 2007) ve Tokat'ta yürütülen çalışmanın sonuçlarıyla (Kandemir 2004) benzerlik göstermektedir. Yapılan bir başka çalışmada ise Suriye ve Ürdün'e ait toplam sekiz adet yerel arpa çeşit popülasyonlarından seçilen homozigot hatları başakta tane sayısı bakımından değerlendirmeye alınmış ve 21-40 adet arasında değişen miktarlarda başakta tane sayısı belirlenmiştir. Ayrıca çalışmada kullanılan hatlar kullanılan kontrol çeşitleri ile karşılaştırıldığında bazı kontrol çeşitlerine nazaran daha düşük başakta tane sayısına sahip olmalarına rağmen ortalama olarak kontrol çeşitlerine yakın değerler göstermişlerdir (Weltzhen ve Fischbeck 1990). En uzun başak boyu 208 numaralı hatta $8,59 \mathrm{~cm}$ ile ölçülmüş ve bu başak boyu ile karşılaştırılan diğer hatlardan belirgin şekilde farklı olmuştur (Çizelge 2). En kısa başak boyu ise 215 numaralı hatta $6,72 \mathrm{~cm}$ ile ölçülmüştür. Hatlar genel olarak kendi aralarında ve Tokak 157/37 (7,18 cm) çeşidi ile aynı istatistiki grupta yer alırken Harrington $(9,16$ $\mathrm{cm})$ çeşidi ile farklı grupta yer almışlardır (Çizelge 2). Akkaya ve Akten (1986) arpada başak uzunluğunun 4,47-7,04 cm arasında değiştiğini ve çeşitlerin başak uzunluğu arasındaki farkın çok önemli olduğunu belirtmişlerdir. Yirmi dokuz yerel arpa çeşidi içinde toplam sekiz yüz aksesyon incelenen bir çalışmada başak uzunluğu bakımından yerel çeşitler içinde homozigot hatlar arasında 4,4 cm'ye varan farklılıklar belirlenmiştir (Akıncı ve Yıldırım 2009). En yüksek 1000 tane ağırlığı 217 numaralı hatta $51,32 \mathrm{~g}$ olarak ölçülmüştür (Çizelge 2). Bu hattı sırasıyla $207(50,54 \mathrm{~g}), 224$ $(50,14 \mathrm{~g})$ ve $208(50,06 \mathrm{~g})$ numaralı hatlar takip etmiştir. En düşük 1000 tane ağırlığı 215 numaralı hatta 40,15 g ile ölçülmüştür. Bu hattı $43,44 \mathrm{~g}$ ile 59. hat takip etmiştir. Denemeye alınan hatlar referans çeşitlerinden Tokak 157/37 ile karşılaştıııldığında Tokak 157/37 çeşidi belirgin bir şekilde en yüksek 1000 tane ağırlığına sahip olmuştur. Referans çeşitlerinden olan Harrington ise denemeye alınan hatlara yakın veya daha yüksek 1000 tane ağırığına sahip olmuştur. Yirmi dokuz yerel çeşit içinde toplam sekiz yüz aksesyon incelenen bir çalışmada 1000 tane ağırlığı bakımından yerel çeşitler içinde homozigot hatlar arasında 29,7 g'a varan farklııklar belirlenmiştir (Akıncı ve Yıldırım 2009). Alemayehu ve Parliet (1997) 18 Etiyopya yerel arpa çeşitleriyle yaptıkları çalışmalarında 1000 tane ağırlığını 21,2-52,7 g arasında değiştiğini bildirmişlerdir. Weltzhen ve Fischbeck (1990) sekiz yerel arpa popülasyonundan seçilen homozigot hatların 1000 tane ağırlıklarının 27,6-40,4 g arasında değiştiğini ve denemeye alınan hatların büyük çoğunluğunun kontrol çeşitlerinden yüksek değere sahip olduğunu bildirmişlerdir. 1000 tane ağırlığı agronomik özellikler içerisinde önemli bir verim ve kalite öğesidir. Maltıı arpada 1000tane ağırığının $40 \mathrm{~g}$ üzerinde olması gerekmektedir (Atlı ve ark. 1989). Bu nedenle denemeye alınan tüm hatlar malt üretimi için yeterli 1000 tane ağırlığına sahip olmuştur. 221 numaralı hat $69,33 \mathrm{~kg}$ ile belirgin bir şekilde yüksek hektolitre ağırlığa sahip olmuş, bunu 68,33 kg ile 210 numaralı hat izlemiştir (Çizelge 2). En düşük değer ise $64,40 \mathrm{~kg}$ ile 208 ve 64,80 $\mathrm{kg}$ ile 53 numaralı hatlardan elde edilmiştir. Harrington çeşidi $68,50 \mathrm{~kg}$ ile en yüksek değere sahip hatta yakın, Tokak $157 / 37$ çeşidi ise $64,63 \mathrm{~kg}$ ile en düşük hatta yakın değere sahip olmuştur. Malttık arpalarda hektolitre ağırlığının 
Çizelge 2. PI 470281 hatları ile Tokak 157/37 ve Harrington çeşitlerinin başakta tane sayısı, başak boyu, 1000 tane ağırlığı ve hektolitre ağırlığına ait değerler

Table 2. Number of seeds per head, spike length, 1000 seed weight and test weight of PI 470281 lines, Tokak 157/37 and Harrington varieties

\begin{tabular}{|c|c|c|c|c|}
\hline & $\begin{array}{l}\text { Başakta tane } \\
\text { sayısı (adet)** }\end{array}$ & $\begin{array}{l}\text { Başak boyu } \\
(\mathrm{cm})^{\star *}\end{array}$ & $\begin{array}{l}1000 \text { tane ağırlığı } \\
(\mathrm{g})^{\star *}\end{array}$ & $\begin{array}{l}\text { Hektolitre ağırlığı } \\
(\mathrm{kg})^{\star *}\end{array}$ \\
\hline Harrington & $27,67 \mathrm{~A}$ & $9,16 \mathrm{~A}$ & 47,54 B-F & $68,50 \mathrm{AB}$ \\
\hline Tokak 157/37 & $21,80 \mathrm{~B}$ & $7,18 \mathrm{CD}$ & $53,60 \mathrm{~A}$ & $64,63 \mathrm{CD}$ \\
\hline 40 & 21,87 B & $7,17 \mathrm{CD}$ & 49,15 A-E & 66,73 A-D \\
\hline 44 & $21,03 \mathrm{~B}$ & $7,50 \mathrm{BCD}$ & 49,25 A-D & 66,40 A-D \\
\hline 46 & $21,83 \mathrm{~B}$ & $7,10 \mathrm{CD}$ & 44,52 D-G & 65,83 A-D \\
\hline 50 & 22,07 B & $7,31 \mathrm{CD}$ & 46,40 B-F & 67,27 A-D \\
\hline 51 & $20,40 \mathrm{~B}$ & $7,11 \mathrm{CD}$ & 44,44 D-G & $65,50 \mathrm{BCD}$ \\
\hline 53 & $20,83 \mathrm{~B}$ & $6,86 \mathrm{CD}$ & 44,00 EFG & 64,80 BCD \\
\hline 56 & $22,23 \mathrm{~B}$ & $8,03 \mathrm{BC}$ & 48,46 B-F & 67,43 A-D \\
\hline 59 & $22,00 \mathrm{~B}$ & $7,08 \mathrm{CD}$ & 43,44 FG & 67,50 A-D \\
\hline 61 & $23,30 \mathrm{~B}$ & $8,08 \mathrm{BC}$ & 48,99 A-E & 67,97 A-D \\
\hline 62 & $21,90 \mathrm{~B}$ & $6,86 \mathrm{CD}$ & 45,22 C-F & 66,97 A-D \\
\hline 64 & $22,73 \mathrm{~B}$ & $7,34 \mathrm{CD}$ & 44,17 D-G & 65,47 BCD \\
\hline 67 & $20,73 \mathrm{~B}$ & $7,36 \mathrm{CD}$ & 46,54 B-F & 66,70 A-D \\
\hline 201 & $22,63 \mathrm{~B}$ & $7,61 \mathrm{BCD}$ & 46,30 B-F & 66,50 A-D \\
\hline 206 & $22,30 \mathrm{~B}$ & $7,30 \mathrm{CD}$ & 47,63 B-F & 67,57 A-D \\
\hline 207 & $21,53 \mathrm{~B}$ & $7,87 \mathrm{BCD}$ & $50,54 \mathrm{AB}$ & 66,10 A-D \\
\hline 208 & 22,77 B & $8,59 \mathrm{AB}$ & $50,06 \mathrm{ABC}$ & $64,40 \mathrm{D}$ \\
\hline 210 & $22,50 \mathrm{~B}$ & $7,32 \mathrm{CD}$ & 46,46 B-F & $68,33 \mathrm{ABC}$ \\
\hline 212 & $22,23 \mathrm{~B}$ & $7,37 \mathrm{CD}$ & 44,22 D-G & 67,27 A-D \\
\hline 213 & $23,00 \mathrm{~B}$ & $7,51 \quad \mathrm{BCD}$ & 48,93 A-E & 65,20 BCD \\
\hline 215 & $21,60 \mathrm{~B}$ & $6,72 \mathrm{D}$ & $40,15 \mathrm{G}$ & 67,33 A-D \\
\hline 217 & $22,67 \mathrm{~B}$ & 7,79 BCD & $51,32 \mathrm{AB}$ & 65,27 BCD \\
\hline 221 & $23,07 \mathrm{~B}$ & $7,35 \mathrm{CD}$ & 48,04 B-F & $69,33 \mathrm{~A}$ \\
\hline 224 & 21,77 B & $7,90 \mathrm{BCD}$ & $50,14 \mathrm{ABC}$ & 67,83 A-D \\
\hline 227 & $22,10 \mathrm{~B}$ & $7,09 \mathrm{CD}$ & 46,50 B-F & 67,00 A-D \\
\hline 228 & $21,60 \mathrm{~B}$ & 7,78 BCD & 48,04 B-F & 67,27 A-D \\
\hline
\end{tabular}

${ }^{* *}$ Aynı harf grubuna giren ortalamalar arasında Duncan testine göre $\% 1$ seviyesinde önemli farklılıklar yoktur.

**There is no significant difference between the groups with the same letters at $1 \%$ level.

66 kg'ın üzerinde olması istenir (Atlı ve ark. 1989). Arpada yüksek hektolitre ağırlığı daha fazla nişasta ve daha fazla malt ekstrakt oranını ifade etmektedir (Engin 1989). Buna göre hektolitre ağılıklarına bakarak maltık arpaların yüksek kalitede olması beklenebilir (Kandemir 2004). Bu açıdan sonuçlar değerlendirildiğinde 221 numaralı hat ve bu hattı takip eden hatlar kontrol çeşitlerinden daha yüksek hektolitre ağırlığına sahip olmuştur. Bu hatlar ileriye dönük olarak yeni çeşitlerin ıslah edilmesinde kaynak olabileceği düşünülmektedir.

\section{Tane verimi, Biyolojik verim ve Hasat indeksi}

Hatlar arasında en yüksek tane verimi 224 numaralı hatta $502,1 \mathrm{~kg} /$ da olarak tespit edilmiştir (Çizelge 3). Bu hattı $501,1 \mathrm{~kg} / \mathrm{da}$ ile 44 numaralı hat ve 488,7 kg/da ile 61 numaralı hat takip etmiştir. Referans çeşitlerinden olan Tokak 157/37 329,1 kg/da tane verimi ile düşük değere sahip olurken, Harrington ise $724,8 \mathrm{~kg} / \mathrm{da}$ ile en yüksek değere sahip olmuştur. Çoğu hattın tane veriminin yaygın kullanılan ticari bir çeşit olan Tokak 157/37'den daha yüksek seviyede gerçekleşmesi bu hatların doğrudan safhat çeşitler olarak kullanılabilme intimalini gündeme getirmekte, ayrıca yerel çeşit içinde verim ıslahı için kullanılabilecek olan genlerin bulunduğuna işaret etmektedir. Ancak incelenen hatlar verim performansı bakımından oldukça iyi durumda olsalar da yatma oranlarının çok yüksek olması böyle bir intimali zayıflatmaktadır. Arpanın Tokat bölgesinde daha çok kışlık yetiştirildiği düşünülürse, hastalıklara duyarlılık ve yatmanın daha fazla görüldüğü kışlık şartlarda bu özellikler 
daha olumsuz şekilde ortaya çıkacaklardır. Bu durum PI 470281 hatlarının doğrudan safhat çeşit olarak kullanılma intimalini düşürmektedir. Ceccarelli ve Grando (2006) yaptıkları çalışmalarında yerel çeşitler ve ticari çeşitleri ideal ve ideal olmayan verim şartlarında denemeye almışlardır. İdeal şartlarda yerel çeşitler ticari çeşitlere nazaran daha düşük tane verimine sahip olurken, ideal olmayan şartlar altında (tuz ve kuraklık stresi gibi) yerel çeşitler ticari çeşitlerden belirgin bir şekilde yüksek tane verimine sahip olmuşlardır. Yapılan farklı bir çalışmada ise, yerel arpa çeşit popülasyonlarından seçilen homozigot hatları değerlendirmeye alınmış ve tane veriminin 260$4850 \mathrm{~kg} / \mathrm{ha}$ arasında değiştiği bildirilmiştir
(Weltzien ve Fischbeck 1990). Biyolojik verim bakımından değerlendirilmeye alınan hatlar 9081408 kg/da arasında değişiklik göstermiştir (Çizelge 3). Referans çeşitlerinden olan Harrington 2018 kg/da olup en yüksek biyolojik verime sahip olmuş ve Tokak 157/37 (1109 kg/da) ile diğer tüm hatlardan farklı istatistiki grupta yer almıştır. PI 470281 hatları hasat indeksleri bakımından \%29,46-42,08 arasında değişen oranlarda hasat indeksine sahip olmuşlardır (Çizelge 3). Daha önce hasat indeksine yönelik çalışmalarda hasat indeksi oranlarının \%30-50 arasında değişim gösterdiği belirlenmiştir (Kenar ve Şehriali 2001; Kaydan ve Yağmur 2007; Sairam ve Singh 1989; Sadıç 1998).

Çizelge 3. PI 470281 hatları ile Tokak 157/37 çeşidi ve Harrington çeşidinin tane verimi, biyolojik verim ve hasat indeksine ait değerler

Table 3. Grain yield, biological yield and harvest index of PI 470281 lines, Tokak 157/37 and Harrington varieties

\begin{tabular}{|c|c|c|c|}
\hline & Tane verimi $(\mathrm{kg} / \mathrm{da})^{*}$ & 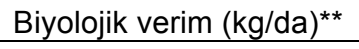 & Hasat indeksi (\%) \\
\hline Harrington & $724,8^{* * *}$ & $2018 \mathrm{~A}$ & 36,29 \\
\hline Tokak 157/37 & $329,1 \mathrm{CD}$ & 1109 B & 28,06 \\
\hline 40 & 441,3 A-D & $1259 \mathrm{~B}$ & 34,36 \\
\hline 44 & $501,1 \mathrm{~A}$ & $1336 \mathrm{~B}$ & 38,52 \\
\hline 46 & $348,6 \mathrm{CD}$ & 1058 B & 29,79 \\
\hline 50 & $384,3 \quad A-D$ & $1122 \mathrm{~B}$ & 35,30 \\
\hline 51 & 323,9 A-D & $926 \mathrm{~B}$ & 31,32 \\
\hline 53 & 401,8 A-D & $1287 \mathrm{~B}$ & 29,46 \\
\hline 56 & 361,1 BCD & $1028 \mathrm{~B}$ & 35,13 \\
\hline 59 & 403,5 A-D & $1077 \mathrm{~B}$ & 36,05 \\
\hline 61 & $488,7 \quad A B$ & $1131 \mathrm{~B}$ & 42,08 \\
\hline 62 & 407,9 A-D & 1039 B & 37,28 \\
\hline 64 & 329,5 CD & 1095 B & 31,12 \\
\hline 67 & 419,7 A-D & 1205 B & 34,96 \\
\hline 201 & $307,9 \mathrm{D}$ & $908 \mathrm{~B}$ & 38,79 \\
\hline 206 & $340,2 \mathrm{CD}$ & 1049 B & 32,29 \\
\hline 207 & $425,3 \mathrm{AB}$ & $1124 \mathrm{~B}$ & 38,15 \\
\hline 208 & 442,3 A-D & $1226 \mathrm{~B}$ & 35,18 \\
\hline 210 & $328,0 \mathrm{CD}$ & 969 B & 32,48 \\
\hline 212 & $448,5 \mathrm{ABC}$ & 1266 B & 34,83 \\
\hline 213 & 374,2 A-D & $1051 \mathrm{~B}$ & 35,91 \\
\hline 215 & 327,2 CD & 946 B & 29,55 \\
\hline 217 & $342,5 \mathrm{CD}$ & 1037 B & 31,89 \\
\hline 221 & 408,3 A-D & $1245 \mathrm{~B}$ & 33,17 \\
\hline 224 & $502,1 \mathrm{~A}$ & 1408 B & 33,68 \\
\hline 227 & $369,3 \quad A-D$ & 929 B & 37,32 \\
\hline 228 & 391,6 A-D & $1080 \mathrm{~B}$ & 37,01 \\
\hline
\end{tabular}

* Aynı harf grubuna giren ortalamalar arasında Duncan testine göre $\% 5$ seviyesinde önemli farklılıklar yoktur. ${ }^{* *}$ Aynı harf grubuna giren ortalamalar arasında Duncan testine göre \%1 seviyesinde önemli farklılıklar yoktur. *** Diğer çeşit ve hatlardan çok daha yüksek tane verimine sahip olan Harrington çeşidi hatlar arasındaki farklılığı görebilmek için analiz dışında tutulmuştur.

*, ${ }^{* *}$ There is no significant difference between the groups with the same letters at $5 \%$ and $1 \%$ level, respectively. ${ }^{* * *}$ The lines of Harrington variety which have more grain yield than the other variety and lines were excluded from the statistical analysis in order to better see the difference between the lines. 


\section{Asit Deterjan Lif (ADF), Nötral Deterjan Lif (NDF), Ham kül ve Ham protein oranı}

Asit Deterjan Lif (ADF); bitki hücre duvarı yapısında selüloz, lignin ve çözünmeyen protein miktarını ifade eder. Ayrıca yem sindirilebilirliği ve hayvanın enerji alımı hakkında da fikir veren iyi bir göstergedir. Yüksek ADF içerikli yemlerin sindirilebilirliği ve enerji değeri düşüktür (Kutlu 2008). Denemeye alınan PI 470281 hatları ADF oranları bakımından değerlendirildiğinde istatistiki olarak \%1 düzeyinde farklılıklar olduğu görülmüştür. En yüksek ADF oranı $\% 9,07$ ile 201 numaralı hatta ölçülmüş ve bu hattı 40 $(\% 8,67), 50(\% 8,43), 213(\% 8,37)$ ve 212 $(\% 8,30)$ numaralı hatlar izlemiştir (Çizelge 4). Hatlar arasında ADF oranları bakımından en düşük ölçüm 61 numaralı hatta $\% 7,03$ ile ölçülmüş, bunu 217 numaralı hat $\% 7,13$ ve 59 numaralı hat \%7,27 ile izlemiştir. Referans çeşitlerinden Harrington ADF miktarı bakımından en düşük değere sahip olmuştur. Denemeye alınan hatlar referans çeşitleriyle karşılaştırıldığında Harrington'dan yüksek, Tokak 157/37'den ise düşük değere sahip olmuşlardır. Han ve ark. (2003), yaptıkları çalışmada üç arpa hattına ait tanelerin ADF miktarlarının $\% 7,52$ ile $\% 7,91$ arasında değiştiğini belirlemişlerdir. Nötral Deterjan Lif (NDF); bitki hücre duvarı yapısında bulunan selüloz, hemiselüloz, lignin, kütin ve çözünmeyen protein miktarını ifade etmektedir. NDF değeri hayvanların yem alımına doğrudan etkili olduğundan, yemde NDF oranı düştükçe hayvanın yem alımı artar (Van Soest ve ark. 1991). Bu açıdan değerlendirildiğinde NDF oranının yüksek olması hayvan besleme açısından istenen bir parametredir. Bu çalışmada en yüksek NDF oranı \%26,61 ile 207 numaralı hatta ölçülmüş bu hattı $206(\% 24,90)$ ve $56(\% 24,76)$ numaralı hatlar takip etmiştir (Çizelge 4). NDF oranları bakımından en düşük oran \%20,46 ile 61 numaralı hatta tespit edilmiş, bunu \%20,48 ile 227 numaralı hat izlemiştir. Referans çeşitlerimizden Harrington çeşidi $\% 19,77$ ile en düşük NDF oranına sahip olmuştur. Denemeye alınan hatlar NDF oranları bakımından referans çeşitlerimizden olan Harrington'dan yüksek çıkmış, Tokak 157/37 çeşidine göre yakın sonuçlar göstermiştir. Fox ve ark. (2003)'nın yaptıkları çalışmada arpanın NDF içeriğinin \%15-30 arasında değiştiğini bildirmişlerdir. Fife ve ark (2008)'nın yürüttükleri çalışmada ise arpa tanesinin NDF içeriğinin $\% 19,9$ ile $\% 24,5$ arasında değiştiğini ortaya koymuşlardır. Arpa tanesindeki kuru maddenin büyük bir kısmını organik maddeler, geri kalanını ise inorganik maddeler oluşturur. Kuru madde usulüne uygun yakıldığında geriye kalan yanmamış maddelerin tümüne "ham kül" adı verilir (Kutlu 2008). Ham kül oranı mineral madde içeriği ile ilişkilidir. Çünkü arpa külünün mineral içeriği esas olarak potasyum ve fosfordan oluşmakta, daha az miktarda ise klor, magnezyum, kükürt, sodyum ve kalsiyum intiva etmektedir. Arpa tanesinin külünde bu mineral maddelerin dışında demir, çinko, bakır, manganez ve selenyum daha az miktarda bulunmaktadır (Owen ve ark. 1977).

Çalışma sonucunda en yüksek ham kül oranı 40 numaralı hatta tespit edilmiş ve bu değer \%2,56 olarak belirlenmiştir (Çizelge 4). Bu hattı 217 (\%2,53), $207(\% 2,50)$ ve 50 $(\% 2,49)$ numaralı hatlar takip etmiştir. En düşük ham kül oranı \%2,04 ile 228 numaralı hatta tespit edilmiştir. Referans çeşitlerinden Tokak $157 / 37 \% 2,55$ ile en yüksek ham kül içeriğine sahip olurken, Harrington \%2,07 düşük ham kül içeriğine sahip olmuştur. Daha önce yapılan çalışmalar sonucunda genel olarak arpanın kül içeriğinin \%2-3 arasında değiştiği, kavuzsuz arpalarda ise bu oranın daha düşük olabileceği bildirilmiştir. En yüksek ham protein oranı 227 numaralı hatta \%14,47 olarak tespit edilmiştir (Çizelge 4). Bu hattı 224 ve 44 numaralı hatlar $(\% 13,67)$ takip etmiştir. En düşük ham protein oranı 46 numaralı hatta $\% 12,00$ ile tespit edilmiştir. Hatların büyük çoğunluğu Harrington $(\% 13,13)$ çeşidine yakın, Tokak 157/37 $(\% 14,73)$ çeşidinden ise daha düşük ham protein oranına sahip olmuşlardır. Protein içeriği maltık arpanın önemli özelliklerinden birisi olup yüksek protein birada renk bulanıklığına, lezzetin acılaşmasına ve dayanıklılığın azalmasına neden olduğundan, protein oranının \%12'den az olması istenmektedir (Kün 1988). Ancak bira yapımında gerekli enzimler, bira mayasının beslenmesi, biranın köpüklenmesi ve besleme değerinin artması için biralık arpada belli düzeyde proteine intiyaç vardır. PI 470281 hatları bu açıdan değerlendirildiğinde \%12'nin üstünde protein oranına sahip olsalar da dünyada iyi tanınan bir maltık arpa çeşidi olan Harrington'dan daha düşük protein oranına sahiptirler. Bu nedenle PI 470281 hatlarının maltlık kullanıma uygun olduğu düşünülebilir. 
Çizelge 4. PI 470281 hatları ile Tokak 157/37 çeşidi ile Harrington çeşidinin asit deterjan lif (ADF), nötral deterjan lif (NDF), ham kül ve ham protein oranına ait değerler

Table 4. Acid detergent fiber (ADF), neutral detergent fiber (NDF), crude ash and crude protein of PI 470281 lines, Tokak 157/37 and Harrington varieties

\begin{tabular}{|c|c|c|c|c|c|}
\hline & $\operatorname{ADF}(\%)^{* *}$ & NDF ( & $\%)^{\star *}$ & Ham kül $(\%)^{\star *}$ & Ham protein $(\%)^{*}$ \\
\hline Harrington & $6,53 \mathrm{~F}$ & 19,77 & $\mathrm{D}$ & $2,07 \mathrm{CD}$ & 13,13 BCD \\
\hline Tokak 157/37 & $8,53 \mathrm{ABC}$ & 23,51 & $A-D$ & $2,55 \mathrm{~A}$ & $14,73 \mathrm{~A}$ \\
\hline 40 & $8,67 \mathrm{AB}$ & 23,56 & $A-D$ & $2,56 \mathrm{~A}$ & $12,40 \mathrm{CD}$ \\
\hline 44 & 8,00 A-E & 24,14 & $A B C$ & 2,34 A-D & $13,67 \mathrm{ABC}$ \\
\hline 46 & 8,23 A-E & 20,95 & BCD & $2,17 \mathrm{BCD}$ & $12,00 \mathrm{D}$ \\
\hline 50 & 8,43 A-D & 24,27 & $A B C$ & $2,49 \mathrm{AB}$ & $13,20 \mathrm{BCD}$ \\
\hline 51 & 7,63 B-F & 22,46 & $A-D$ & 2,38 A-D & $12,97 \mathrm{BCD}$ \\
\hline 53 & $7,97 \mathrm{AB}$ & 20,94 & BCD & 2,39 A-D & $12,70 \mathrm{CD}$ \\
\hline 56 & 7,83 A-E & 24,76 & $A B C$ & 2,23 A-D & $13,37 \quad A-D$ \\
\hline 59 & $7,27 \mathrm{C}-\mathrm{F}$ & 21,35 & BCD & 2,34 A-D & $12,27 \mathrm{CD}$ \\
\hline 61 & $7,03 \mathrm{EF}$ & 20,46 & $C D$ & 2,31 A-D & $12,27 \mathrm{CD}$ \\
\hline 62 & 8,00 A-E & 21,88 & BCD & $2,43 \mathrm{ABC}$ & 13,27 A-D \\
\hline 64 & 8,17 A-E & 22,89 & $A-D$ & 2,36 A-D & $13,13 \mathrm{BCD}$ \\
\hline 67 & 7,50 B-F & 23,71 & $A-D$ & 2,28 A-D & $12,77 \mathrm{CD}$ \\
\hline 201 & $9,07 \mathrm{~A}$ & 23,42 & $A-D$ & 2,30 A-D & $12,30 \mathrm{CD}$ \\
\hline 206 & 7,83 A-E & 24,90 & $A B$ & $2,16 \mathrm{BCD}$ & $12,67 \mathrm{CD}$ \\
\hline 207 & 7,47 B-F & 26,61 & A & $2,50 \mathrm{AB}$ & 13,17 BCD \\
\hline 208 & 7,87 A-E & 23,98 & $A-D$ & 2,40 A-D & $13,13 \mathrm{BCD}$ \\
\hline 210 & 7,67 B-F & 21,05 & BCD & 2,17 BCD & $12,50 \mathrm{CD}$ \\
\hline 212 & 8,30 A-E & 22,89 & $A-D$ & 2,32 A-D & 12,97 BCD \\
\hline 213 & 8,37 A-E & 21,43 & BCD & 2,22 A-D & 13,30 A-D \\
\hline 215 & 8,13 A-E & 22,43 & $A-D$ & 2,32 A-D & $12,60 \mathrm{CD}$ \\
\hline 217 & 7,13 DEF & 23,24 & $A-D$ & $2,53 \mathrm{AB}$ & $12,93 \mathrm{BCD}$ \\
\hline 221 & 8,03 A-E & 22,50 & $A-D$ & 2,39 A-D & $12,17 \mathrm{CD}$ \\
\hline 224 & 8,07 A-E & 23,29 & $A-D$ & $2,41 \mathrm{ABC}$ & $13,67 \mathrm{ABC}$ \\
\hline 227 & 8,13 A-E & 20,48 & $C D$ & 2,26 A-D & $14,47 \mathrm{AB}$ \\
\hline 228 & 8,00 A-E & 22,06 & $\mathrm{BCD}$ & $2,04 \mathrm{D}$ & $13,13 \mathrm{BCD}$ \\
\hline
\end{tabular}

${ }^{*}$ Aynı harf grubuna giren ortalamalar arasında Duncan testine göre $\% 5$ seviyesinde önemli farklılıklar yoktur. ${ }^{* *}$ Aynı harf grubuna giren ortalamalar arasında Duncan testine göre \%1 seviyesinde önemli farklılıklar yoktur.

*, ${ }^{* *}$ There is no significant difference between the groups with the same letters at $5 \%$ and $1 \%$ level, respectively.

\section{Makro Element (P, K, Ca, Mg) Konsantrasyonları}

Mineral madde analizi sonucunda fosfor değerleri incelendiğinde en yüksek fosfor konsantrasyonu 227 numaralı hatta 3679,3 $\mathrm{mg} / \mathrm{kg}$ olarak ölçülmüştür (Çizelge 5 ). Bu değeri $3677,0 \mathrm{mg} / \mathrm{kg}$ ile 217 numaralı hat ve $3676,2 \mathrm{mg} / \mathrm{kg}$ ile 40 numaralı hat takip etmiştir. En düşük fosfor konsantrasyonu $3011,2 \mathrm{mg} / \mathrm{kg}$ ile 215 numaralı hatta ölçülmüş ve bu hattı 206 $(3053,7 \mathrm{mg} / \mathrm{kg})$ ile $46(3077,1 \mathrm{mg} / \mathrm{kg})$ numaralı hatlar takip etmiştir. Kontrol çeşitlerinden Harrington 2690,8 mg/kg konsantrasyonu ile en düşük, Tokak $157 / 37$ ise $3898,6 \mathrm{mg} / \mathrm{kg}$ ile en yüksek fosfor konsantrasyonuna sahip olmuştur. Villacres ve Rivadeneira (2005) yaptıkları çalışmada arpada fosfor konsantrasyonunun $2400 \mathrm{mg} / \mathrm{kg}$ ile 4700 $\mathrm{mg} / \mathrm{kg}$ arasında değiştiğini bildirmişlerdir. Bu açıdan tane bileşimi değerlendirildiğinde denemeye alınan hatların fosfor bileşimi açısından zengin olduğu düşünülmektedir. Bitkiler fazla miktarda potasyuma intiyaç duyarlar. Potasyum sitoplazmada en çok bulunan katyondur. Fotosentezin gerçekleşmesinde, enzim aktivitesinde ve bitkilerin su içeriklerinin düzenlenmesinde önemli görevleri vardır. Bu nedenlerden dolayı, 
potasyum sadece yetiştirme ve verim için önemli değil aynı zamanda tahılların şeker ve protein içerikleri içinde önemlidir (Kaçar ve Katkat 1998; Güneş ve ark. 2000). İncelenen hatlar arasında potasyum konsantrasyonu bakımından en yüksek değer 207 numaralı hatta $4742,7 \mathrm{mg} / \mathrm{kg}$ bulunmuştur (Çizelge 5 ). Bu hattı 4729,3 mg/kg ile 227 ve 4623,8 mg/kg ile 213 numaralı hatlar izlemiştir. Hatlar arasındaki en düşük potasyum konsantrasyonu 59 numaralı hatta 3886 , $4 \mathrm{mg} / \mathrm{kg}$ olarak belirlenmiştir. Referans çeşitlerimizden Tokak 157/37 yüksek miktarda potasyum konsantrasyonuna sahip olurken, Harrington çeşidi nispeten daha düşük potasyum konsantrasyonuna sahip olmuştur. PI hatlarının büyük çoğunluğu Tokak 157/37 ile aynı istatistiki grupta yer alırken, denemeye alınan hatların tümü Harrington çeşidi ile farklı istatistiki grupta yer almıştır. Stewart ve ark. (1988) yılında yaptıkları çalışmada tanede en yüksek miktarda potasyumun bulunduğunu ve toplam mikro element miktarının yaklaşık \%45'ini bu elementin oluşturduğunu bildirmektedirler. Villacres ve Rivadeneira (2005) yaptıkları çalışmada arpanın potasyum içeriğini $2200 \mathrm{mg} / \mathrm{kg}$ ile $4800 \mathrm{mg} / \mathrm{kg}$ arasında değiştiğini bildirmişlerdir. Kalsiyum konsantrasyonu bakımından hatlar incelendiğinde en yüksek kalsiyum içeriği 51 numaralı hatta $428,7 \mathrm{mg} / \mathrm{kg}$ ile belirlenmiştir (Çizelge 5). Bu değeri 423,4 mg/kg ile 228 numaralı hat takip etmiştir. Denemeye alınan hatlar arasında en düşük kalsiyum

Çizelge 5. PI 470281 hatları ile Tokak 157/37 çeşidi ve Harrington çeşidinin kuru yakma metodu ile ICP cihazında $\mathrm{P}, \mathrm{K}, \mathrm{Ca}$ ve $\mathrm{Mg}$ değerleri

Table 5. P, K, Ca and Mg contents in seeds of PI 470281 lines, Tokak 157/37 and Harrington varieties

\begin{tabular}{|c|c|c|c|c|}
\hline & $\mathrm{P}(\mathrm{mg} / \mathrm{kg})^{\star *}$ & $\mathrm{~K}(\mathrm{mg} / \mathrm{kg})^{* *}$ & $\mathrm{Ca}(\mathrm{mg} / \mathrm{kg})^{* *}$ & $\mathrm{Mg}(\mathrm{mg} / \mathrm{kg})^{* \star}$ \\
\hline Harrington & $2690,8 \mathrm{C}$ & $3720,7 \mathrm{C}$ & $422,7 \mathrm{~A}$ & $1161,5 \mathrm{D}$ \\
\hline Tokak 157/37 & $3898,6 \mathrm{~A}$ & $4526,6 \mathrm{~A}$ & 325,5 BCD & $1373,4 \mathrm{ABC}$ \\
\hline 40 & 3676,2 AB & $4537,4 \mathrm{~A}$ & 384,8 A-D & $1439,1 \mathrm{~A}$ \\
\hline 44 & $3411,5 \mathrm{AB}$ & $4439,4 \mathrm{~A}$ & $317,3 \mathrm{CD}$ & $1340,2 \mathrm{ABC}$ \\
\hline 46 & $3077,1 \mathrm{BC}$ & 4298,9 AB & 364,0 A-D & $1317,0 \quad A-D$ \\
\hline 50 & $3328,1 \mathrm{ABC}$ & 4389,9 AB & 384,2 A-D & $1337,9 \mathrm{ABC}$ \\
\hline 51 & 3466,2 AB & $4243,7 \quad A B$ & $428,7 \mathrm{~A}$ & 1377,8 ABC \\
\hline 53 & 3614,7 AB & $4570,7 \mathrm{~A}$ & 390,0 A-D & $1380,5 \mathrm{AB}$ \\
\hline 56 & 3610,6 AB & $4477,6 \mathrm{~A}$ & 333,8 BCD & $1413,4 \mathrm{AB}$ \\
\hline 59 & $3426,1 \mathrm{AB}$ & $3886,4 \mathrm{BC}$ & 359,2 A-D & $1366,3 \mathrm{ABC}$ \\
\hline 61 & $3310,9 \mathrm{ABC}$ & $4574,7 \mathrm{~A}$ & 397,3 ABC & 1301,4 A-D \\
\hline 62 & $3456,7 \mathrm{AB}$ & $4338,4 \mathrm{AB}$ & $408,7 \mathrm{AB}$ & $1313,3 \quad A-D$ \\
\hline 64 & $3331,1 \mathrm{ABC}$ & $4531,7 \mathrm{~A}$ & 369,9 A-D & 1326,6 ABC \\
\hline 67 & $3134,9 \mathrm{BC}$ & $4605,2 \mathrm{~A}$ & $409,5 \mathrm{AB}$ & 1281,1 A-D \\
\hline 201 & 3518,5 AB & $4560,8 \mathrm{~A}$ & $383,4 \quad A-D$ & $1378,5 \mathrm{AB}$ \\
\hline 206 & $3053,7 \mathrm{BC}$ & $4324,5 \mathrm{AB}$ & 348,0 A-D & $1358,2 \mathrm{ABC}$ \\
\hline 207 & $3105,5 \mathrm{BC}$ & $4742,7 \mathrm{~A}$ & 306,7 D & $1214,1 \mathrm{CD}$ \\
\hline 208 & $3125,4 \mathrm{BC}$ & $4594,5 \mathrm{~A}$ & 368,2 A-D & $1265,6 \mathrm{BCD}$ \\
\hline 210 & $3366,8 \quad A B$ & $4445,0 \mathrm{~A}$ & 376,4 A-D & $1326,2 \mathrm{ABC}$ \\
\hline 212 & $3412,1 \mathrm{AB}$ & $4366,2 \mathrm{AB}$ & $400,5 \mathrm{ABC}$ & $1372,0 \mathrm{ABC}$ \\
\hline 213 & $3475,7 \quad A B$ & $4623,8 \mathrm{~A}$ & 372,7 A-D & $1422,8 \quad A B$ \\
\hline 215 & 3011,2 BC & $4287,4 \quad A B$ & 343,8 A-D & $1340,7 \mathrm{ABC}$ \\
\hline 217 & $3677,0 \quad A B$ & $4487,5 \mathrm{~A}$ & 332,9 BCD & $1356,0 \mathrm{ABC}$ \\
\hline 221 & 3253,3 ABC & $4331,0 \quad A B$ & $403,0 \mathrm{ABC}$ & 1309,6 A-D \\
\hline 224 & 3508,6 AB & $4609,0 \mathrm{~A}$ & 350,5 A-D & $1374,8 \mathrm{ABC}$ \\
\hline 227 & $3679,3 \mathrm{AB}$ & $4729,3 \mathrm{~A}$ & 385,4 A-D & $1410,9 \mathrm{AB}$ \\
\hline 228 & $3208,5 \mathrm{BC}$ & $4368,4 \quad A B$ & $423,4 \mathrm{~A}$ & $1290,0 \quad A-D$ \\
\hline
\end{tabular}

** Aynı harf grubuna giren ortalamalar arasında Duncan testine göre \%1 seviyesinde önemli farklılıklar yoktur.

**There is no significant difference between the groups with the same letters at $1 \%$ level. 
konsantrasyonuna sahip hat ise 207 numaralı hat olup kalsiyum değeri $306,7 \mathrm{mg} / \mathrm{kg}$ olarak belirlenmiştir. Referans çeşitlerimizden Harrington çeşidi $422 \mathrm{mg} / \mathrm{kg}$ yüksek kalsiyum konsantrasyonuna sahip olurken, Tokak $157 / 37$ çeşidi ise $325,5 \mathrm{mg} / \mathrm{kg}$ ile nispeten düşük kalsiyum konsantrasyonuna sahip olmuştur. PI 470281 hatlarının büyük çoğunluğu Harrington çeşidinden düşük kalsiyum konsantrasyonuna sahip olurken, Tokak 157/37 çeşidinden daha yüksek kalsiyum konsantrasyonuna sahip olmuşlardır. Carr ve ark. (2004) yaptıkları çalışmada iki sıralı, üç arpa çeşidinin tanelerinin kalsiyum miktarlarını incelemişler ve tanelerin 295 $\mathrm{mg} / \mathrm{kg}$ ile $365 \mathrm{mg} / \mathrm{kg}$ arasında değişen miktarlarda kalsiyum konsantrasyonuna sahip olduğunu bildirmişlerdir. $\mathrm{Bu}$ sonuçlarla çalışmamızın sonuçları benzerlik göstermektedir. Denemeye alınan hatlar magnezyum içerikleri bakımından incelendiğinde 40 numaralı hat $1439,1 \mathrm{mg} / \mathrm{kg}$ magnezyuma sahip olmuş, bunu 213 numaralı hat $(1422,8 \mathrm{mg} / \mathrm{kg})$ ve 56 numaralı hat $(1413,4$ $\mathrm{mg} / \mathrm{kg}$ ) takip etmiştir (Çizelge 5). Denemeye alınan hatlar arasında en düşük magnezyum konsantrasyonuna sahip hat 207 numaralı hat $(1214,1 \mathrm{mg} / \mathrm{kg})$ olmuştur. Referans çeşitlerimizden Tokak 157/37 denemeye alınan hatların çoğundan daha yüksek (1373,4 $\mathrm{mg} / \mathrm{kg})$, Harrington ise daha düşük $(1161,5$ $\mathrm{mg} / \mathrm{kg}$ ) magnezyum içeriğine sahip olmuştur. Daha önceki çalışmalarda araştırıcılar arpa tanesinin magnezyum içeriğinin $1200 \mathrm{mg} / \mathrm{kg}$ ile $1600 \mathrm{mg} / \mathrm{kg}$ arasında değiştiği bildirmiştir (Anonim 2012; Byrne 1974). Bu sonuçlar ile çalışmamızın sonuçları paralellik göstermektedir.

Mikro Element ( $\mathrm{Fe}, \mathrm{Cu}, \mathrm{Mn}$ ve $\mathrm{Zn})$ Konsantrasyonları

Demir klorofilin yapısında yer almamakla beraber, bitkinin demir beslenmesi ile klorofil içeriği arasında yakın bir ilişki bulunmaktadır. Demir protein sentezi üzerinde de etkilidir (Marschner 1995). Denemeye alınan hatlar demir konsantrasyonları bakımından değerlendirildiğinde 215 numaralı hat 44,5 $\mathrm{mg} / \mathrm{kg}$ ile en yüksek değere sahip hat olmuştur (Çizelge 6). Bu hattı $224(37,7 \mathrm{mg} / \mathrm{kg})$ ve 201 $(36,4 \mathrm{mg} / \mathrm{kg})$ numaralı hatlar takip etmiştir. En düşük demir konsantrasyonuna sahip hattın ise $24,8 \mathrm{mg} / \mathrm{kg}$ ile 213 numaralı hat olduğu belirlenmiştir. Bu hattı $40(25,4 \mathrm{mg} / \mathrm{kg})$ ve 208 $(26,9 \mathrm{mg} / \mathrm{kg})$ numaralı hatlar takip etmiştir. Daha önce Kandemir ve ark (2005) yaptıkları çalışmada beş arpa çeşidini mineral madde yönleriyle incelemiş ve bunlar içerisinden Harrington'un demir içeriğini 44,8 mg/kg olarak tespit etmişlerdir. Çalışmamızdaki hatlar Harrington'dan da yüksek demir konsantrasyonuna sahip olmuşlardır. Villacres ve Rivadeneira (2005) yaptıkları çalışmada arpa tanesinde demir konsantrasyonunun $26 \mathrm{mg} / \mathrm{kg}$ ile $72 \mathrm{mg} / \mathrm{kg}$ arasında değiştiğini bildirmişlerdir. Bu çalışmanın sonuçları ile PI hatlarından elde edilen sonuçlar paralellik göstermektedir.

Bakır bitki fizyolojisi açısından önemli bir elementtir. Vitamin, karbonhidrat ve protein sentezi ile fotosentez ve solunum gibi çok sayıda komplike olayda görev alır. Ayrıca enzimlerin işleyişinde görevlidir (Kaçar ve Katkat 2010). Bakır miktarları yönüyle hatlar incelendiğinde en yüksek bakır konsantrasyonuna sahip hat $8,50 \mathrm{mg} / \mathrm{kg}$ ile 207 numaralı hat olmuştur (Çizelge 6). Bu hattı $8,34 \mathrm{mg} / \mathrm{kg}$ bakır konsantrasyonu ile 228 numaralı hat takip etmiştir. En düşük bakır konsantrasyonu ise 50 numaralı hatta 5,42 $\mathrm{mg} / \mathrm{kg}$ olarak bulunmuş ve bu hattı $6,03 \mathrm{mg} / \mathrm{kg}$ ile 210 numaralı hat takip etmiştir. Referans çeşitlerimizden Tokak 157/37 6,25 mg/kg bakır konsantrasyonuna sahip olurken, Harrington $5,57 \mathrm{mg} / \mathrm{kg}$ ile düşük bakır konsantrasyonuna sahip olmuştur. PI 479281 hatlarının büyük çoğunluğu referans çeşitlerimizden yüksek bakır konsantrasyonuna sahip olmuşlardır. Kandemir ve ark. (2005) yaptıkları çalışmada beş çeşit arpayı bazı mineral maddeleri yönüyle değerlendirmeye almışlar ve sonuç olarak bakır konsantrasyonlarının 3,0-6,4 mg/kg arasında değiştiğini bildirmişlerdir.

Mangan kolay yükseltgenmesi nedeniyle bitkilerde fotosentezde elektron aktarımı ve oksijen içermeyen radikallerin zehir etkilerinin giderilmesi gibi redoks işlemlerinde önemli görevler yapar (Kaçar ve Katkat 2010). Mangan miktarı bakımından hatlar değerlendirildiğinde en yüksek mangan konsantrasyonu 40 numaralı hatta $21,2 \mathrm{mg} / \mathrm{kg}$ ile belirlenmiştir (Çizelge 6). Bu hattı $224(20,3 \mathrm{mg} / \mathrm{kg})$ numaralı hat izlemiştir. En düşük mangan konsantrasyonu 217 ve 207 numaralı hatta $15,4 \mathrm{mg} / \mathrm{kg}$ olarak belirlenmiştir. Referans çeşitlerimizden Harrington ve Tokak $157 / 37$ aynı miktarda $(15,8 \mathrm{mg} / \mathrm{kg})$ mangan içeriğine sahip olmuş ve hatlarımızın neredeyse tamamı referans çeşitlerimizden daha yüksek mangan konsantrasyonuna sahip olmuştur. Kandemir ve ark. (2005) arpa çeşitlerinde mangan konsantrasyonunun $8 \mathrm{mg} / \mathrm{kg}$ ile 11,4 $\mathrm{mg} / \mathrm{kg}$ arasında değiştiğini bildirmişlerdir. Bu 
sonuçlar ile PI hatlarından elde edilen sonuçlar karşılaştırıldığında $\mathrm{PI}$ hatlarının mangan konsantrasyonunun daha yüksek olduğu görülmektedir.

Çinko bitkide karbonhidrat, protein ve oksin metabolizmasında rol oynar. Bazı enzimler ve proteinlerin kritik bileşenidir (Marschner 1995). Enzimler ile substrat bağları arasında bağlanma ve yönlendirmede de rol oynamaktadır (Cakmak 2000). Ayrıca çinko bitkide doğrudan RNA sentezine katkıda bulunduğu ve çinko noksanlığında RNA sentezinin ve buna bağlı olarak protein üretiminin durduğu bildirilmiştir (Price 1962). Çinko konsantrasyonu incelendiğinde hatlar arasında en yüksek çinko konsantrasyonu 217 numaralı hatta $39,16 \mathrm{mg} / \mathrm{kg}$ olarak belirlenmiş, bu hattı $224(36,17 \mathrm{mg} / \mathrm{kg})$ $221(36,13 \mathrm{mg} / \mathrm{kg})$ ve $40(36,11 \mathrm{mg} / \mathrm{kg})$ numaral hatlar izlemiş̧ir (Çizelge 6). En düşük çinko konsantrasyonu 215 numaralı hatta $28,41 \mathrm{mg} / \mathrm{kg}$ olarak belirlenmiş ve bu hattı $61(28,74 \mathrm{mg} / \mathrm{kg})$ ve $206(29,65 \mathrm{mg} / \mathrm{kg})$ numaralı hatlar takip etmiştir. Referans çeşitlerinden Tokak 157/37 en yüksek $(47,80 \mathrm{mg} / \mathrm{kg})$ çinko konsantrasyonuna sahip olmuş, Harrington çeşidi ise düşük $(28,83$ $\mathrm{mg} / \mathrm{kg}$ ) çinko konsantrasyonuna sahip olmuştur. Villacres ve Rivadeneira (2005) yaptıkları çalışmada arpadaki çinko konsantrasyonlarının $30 \mathrm{mg} / \mathrm{kg}$ ile $50 \mathrm{mg} / \mathrm{kg}$ arasında değiştiğin bildirmişlerdir. Bu sonuçlar ile PI 470281 hatlarından elde edilen çinko konsantrasyonları paralellik göstermektedir.

Çizelge 6. PI 470281 hatları ile Tokak 157/37 çeşidi ve Harrington çeşidinin kuru yakma metodu ile ICP cihazında $\mathrm{Fe}, \mathrm{Cu}, \mathrm{Mn}$ ve $\mathrm{Zn}$ değerleri

Table 6. Fe, Cu, Mn and Zn contents in seeds of PI 470281 lines, Tokak 157/37 and Harrington varieties

\begin{tabular}{|c|c|c|c|c|}
\hline & $\mathrm{Fe}(\mathrm{mg} / \mathrm{kg})^{\star *}$ & $\mathrm{Cu}(\mathrm{mg} / \mathrm{kg})$ & $\mathrm{Mn}(\mathrm{mg} / \mathrm{kg})^{\star \star}$ & $\mathrm{Zn}(\mathrm{mg} / \mathrm{kg})^{\star *}$ \\
\hline Harrington & $36,0 \mathrm{AB}$ & 5,57 & $15,8 \mathrm{D}$ & $28,83 \mathrm{C}$ \\
\hline Tokak 157/37 & 32,7 B & 6,25 & $15,8 \mathrm{D}$ & $47,80 \mathrm{~A}$ \\
\hline 40 & 25,4 B & 7,14 & $21,2 \mathrm{~A}$ & $36,11 \mathrm{BC}$ \\
\hline 44 & $29,3 \mathrm{~B}$ & 6,83 & $18,7 \quad A-D$ & $33,08 \quad B C$ \\
\hline 46 & $31,7 \mathrm{~B}$ & 6,36 & $19,7 \mathrm{ABC}$ & $29,80 B C$ \\
\hline 50 & $34,1 \mathrm{AB}$ & 5,42 & $17,5 \mathrm{BCD}$ & $32,77 \mathrm{BC}$ \\
\hline 51 & 27,8 B & 6,07 & $17,5 \mathrm{BCD}$ & $30,91 \mathrm{BC}$ \\
\hline 53 & 29,3 B & 6,28 & $19,5 \mathrm{ABC}$ & $35,06 \mathrm{BC}$ \\
\hline 56 & 28,7 B & 7,72 & $19,7 \mathrm{ABC}$ & $34,78 \mathrm{BC}$ \\
\hline 59 & 30,7 B & 6,72 & $16,3 \mathrm{CD}$ & $33,89 \mathrm{BC}$ \\
\hline 61 & $28,5 \mathrm{~B}$ & 6,65 & $16,8 \mathrm{BCD}$ & $28,74 \mathrm{C}$ \\
\hline 62 & $29,5 \mathrm{~B}$ & 7,33 & $17,6 \mathrm{BCD}$ & $34,57 \mathrm{BC}$ \\
\hline 64 & $28,5 \mathrm{~B}$ & 7,80 & 18,7 A-D & $34,07 \mathrm{BC}$ \\
\hline 67 & $31,3 \mathrm{~B}$ & 7,80 & 17,2 BCD & $29,34 \mathrm{C}$ \\
\hline 201 & $36,4 \quad A B$ & 6,25 & 17,5 BCD & $33,29 \mathrm{BC}$ \\
\hline 206 & 27,4 B & 7,90 & 17,4 BCD & $29,65 \mathrm{C}$ \\
\hline 207 & 29,2 B & 8,50 & $15,4 \mathrm{D}$ & $31,58 \mathrm{BC}$ \\
\hline 208 & 26,9 B & 6,68 & $16,5 \mathrm{CD}$ & $32,18 \mathrm{BC}$ \\
\hline 210 & $31,3 \mathrm{~B}$ & 6,03 & 17,0 BCD & $31,96 \mathrm{BC}$ \\
\hline 212 & $32,8 \mathrm{~B}$ & 7,37 & $17,8 \mathrm{BCD}$ & $32,90 \mathrm{BC}$ \\
\hline 213 & 24,8 B & 6,83 & $17,3 \mathrm{BCD}$ & $34,43 \mathrm{BC}$ \\
\hline 215 & $44,5 \mathrm{~A}$ & 7,45 & 16,9 BCD & $28,41 \mathrm{C}$ \\
\hline 217 & $32,5 \mathrm{AB}$ & 8,11 & $15,4 \mathrm{D}$ & $39,16 \mathrm{~B}$ \\
\hline 221 & $30,7 \mathrm{~B}$ & 6,17 & $16,9 \mathrm{BCD}$ & $36,13 \mathrm{BC}$ \\
\hline 224 & $37,7 \mathrm{AB}$ & 7,96 & $20,3 \mathrm{AB}$ & $36,17 \mathrm{BC}$ \\
\hline 227 & 27,7 B & 6,88 & $18,4 \quad A-D$ & $30,38 \mathrm{BC}$ \\
\hline 228 & 28,7 B & 8,34 & $17,1 \mathrm{BCD}$ & $29,90 \mathrm{BC}$ \\
\hline
\end{tabular}

${ }^{* *}$ Aynı harf grubuna giren ortalamalar arasında Duncan testine göre \%1 seviyesinde önemli farklılıklar yoktur.

**There is no significant difference between the groups with the same letters at $1 \%$ level. 


\section{Sonuç}

Spesifik bir yerel çeşit içinde bulunan safhatların detaylı agronomik ve kalite analizlerine tabi tutulduğu bu çalışmada, tane verimi ve bazı kalite özellikleri de dahil incelenen özelliklerin büyük bir kısmında önemli varyasyonlar belirlenmiştir. $\mathrm{Bu}$ varyasyonlar çoğu kez ticari üretimi yapılan iki arpa çeşidinden daha üstün olmayı da içermektedir. Bu durum yerel çeşitlerin bitki ıslahında kullanılabilme potansiyelini bir kez daha ortaya koymaktadır.

\section{Teşekkür}

Bu çalışma; TOVAG 1070103 no'lu proje kapsamında TÜBITAK tarafından desteklenmiştir. Ayrıca bu çalışmayı maddi olarak destekleyen GOÜ Bilimsel Araştırma Projeleri Komisyonuna teşekkür ederiz.

\section{Kaynaklar}

Aghaee-Sarbarzeh M., Yousef A., Ansary Y., Ketata H. and Mozafary J., 2005. Food Barley; Importance, Uses and Local Knowledge. International Center for Agricultural Research in the Dry Areas, ICARDA, pp. 88-98

Akar T., Avcı M., Düşünceli F., Tosun H., Ozan N., Albustan S., Yalvaç K, Sayım I., Özen D., Sipahi H. 1999. Orta Anadolu ve geçit bölgelerinde arpa tarımının sorunları ve çözüm yolları, Hububat Sempozyumu, Konya 77-86

Akdeniz H., Keskin B., Yılmaz I.,, Oral E., 2004. Bazı Arpa Çeşitlerinin Verim ve Verim Unsurları ile Bazı Kalite Özellikleri Üzerinde Bir Araştırma. Yüzüncü Yıl Üniversitesi, Ziraat Fakültesi, Tarım Bilimleri Dergisi, 14 (2): 119-125

Akkaya A. ve Akten Ş., 1986. Kıraç koşullarda farklı gübre uygulamalarının bazı kışlık arpa çeşitlerinde kışa dayanıklıık ve dane veri ile bazı verim öğelerine etkisi. Doğa, Tr. Tar. Or. D., 10(2): 127-140

Akıncı C. and Yıldırım M., 2009. Screening of barley landraces by direct selection for crop improvement, Acta Agriculturae Scandinavica Section B - Soil and Plant Science, 59: 33-41

Alemayehu F. and Parlevliet J.E., 1997. Variation between and within Ethiopian barley landraces. Euphytica, 94: 183-189

Anderson M.K., Reinbergs E. and Rasmusson D.C., 1985. Barley Breeding, American Society of Agronomy, 26: 231-268

Anonim, 2010. http://www.genbilim.com/content/view /290117/75/
Anonim, 2011. Tokat Meteoroloji Müdürlüğü.

Anonim, 2012. http://www.ag.ndsu.edu/pubs/ansci/sh eep/eb71w.htm

Assefa A., 2005. Biochemical and morfological variation among barley landraces. African Crop Science Journal, 13(4): 227-238

Atlı A., Koçak N., Köksel H. ve Tuncer T., 1989. Yemlik ve maltlık arpada kalite kriterleri ve arpa Islah programlarında kalite değerlendirmesi. Arpa Malt Semineri, Konya: 23-37

Bekele B., Alemayehu F. and Lakew B., 2005. Food Barley; Importance, Uses and Local Knowledge. International Center for Agricultural Research in the Dry Areas, ICARDA, pp. 53-82

Byrne I. and Rasmusson D.C. 1974. Recurrent selection for mineral content in wheat and barley. Euphytica. 23: 241-249

Cakmak I., 2000. Possible roles of zinc in protecting plant cells from damage by reactive oxygen species. New Phytologist, 146: 185-205

Carr P. M., Horsley R.D. and Poland W. W., 2004. Barley, Oat, and Cereal-Pea Mixtures as Dryland Forages in the Northern Great Plains. Published in Agron. J., 96;677-684

Ceccarelli S., Grando, S. and Van Leur J.A.G., 1987. Genetic diversity in barley landraces from Syria and Jordan, Euphytica, 98; 269-280

Ceccarelli S. and Grando S., 2000. Barley landraces from the fertile crescent: a lesson for plant breeders, In Brush SB (eds) Genes in the field, Farm Conservation of Crop Diversity, IPGRI Rome, IDRC Ottawa, Lewis Boca Raton, 51-76

Ceccarelli S.and Grando S., 2006. Chapter 3. Barley land races from the Fertile Crescent: a lesson for plant breeders. IDRC Bulletin

Engin A., 1989. Biralık arpalarda önemli kalite özellikleri ve bunların malt kalitesi üzerine etkileri. Arpa Malt Semineri, 30 Mayıs1 Haziran, Konya, 38-41

Fife T. E., Szasz J. I., Hunt PAS. C. W. and Ahola J. A., 2008. Relationship Between Quality Characteristics of Barley Grain and Digestibility in Feedlot Steers. The Professional Animal Scientist, 24: 560-565

Fox G. P., Panozzo Jç F., Li C. D., Lance R. C. M., Inkerman, P. A., Henry, R. J., 2003. Molecular basis of barley quality. Australian Journal of Agricultural Research, 54: 1081-1101

Freed R. and Eisensmith S. P., 1986. MSTAT Statistical Software for Agronomists. Agron. Abst 
Grando S., and Macpherson H. G., 2005. Food barley; Importance, Uses and Local Knowledge. International Center for Agricultural Research in the Dry Areas, ICARDA, pp. 156

Guo T. R., Zhang G. P., Zhou M. X., Wu F. B. and Chen J. X., 2003. Genotypic Difference in Plant Growth and Mineral Composition in Barley Under Aluminum Stres. Agricultural Sciences in China, 2 (5): 494-501

Güneş A., Alpaslan M., İnal A., 2000. Bitki Besleme ve Gübreleme. Ankara Üniversitesi Ziraat Fakültesi, Yayın No:1514, Ders Kitabı, 467 s, Ankara

Han F., Ullrich S. E., Romagosa I., Clancy J. A., Frooseth J. A., Wesenberg D. M., 2003. Quantitative genetic analysis of acid detergent fiber content in barley. J. Cereal Sci, 38:167172

Harlan J.R., 1975. Our vanishing genetic resources. Science, 188: 618-621

Jaradat A. A., Shahid M. and Al-Maskri, A., 2004. Genetic diversity in the Batini barley landrace from Oman: I. Spike and seed quantitative and qualitative traits. Crop Science, 44: 304-315

Kaçar B. ve Katkat A. V., 1998. Bitki Besleme. Uludağ Üniversitesi Güçlendirme Vakfı Yayın No: 127. Vipaş Yayınları: 3, Bursa

Kaçar B. ve Katkat A. V., 2010. Bitki Besleme. Nobel Yayın Dağıtım. 659 s. ISBN: 978-975-591834-4

Kandemir N., Jones B. L., Wesenberg D. M., Ullrich S. E. and Kleinhofs A., 2000. Marker Assisted Analysis of Three Grain Yield QTL in Barley (Hordeum vulgare L.) Using Near İsogenic Lines, Molecular Breeding, 6:157-167

Kandemir N., 2004. Tokat-Kazova Şartlarına Uygun Maltıı Arpa Çeşitlerinin Belirlenmesi. Gaziosmanpaşa Üniv. Ziraat Fakültesi Dergisi, $21(2): 94-100$

Kandemir N., Tüzen M., Sarı H. and Mendil D., 2005. An Increase of The Mineral Content of Barley Grain by Genotype, Planting Time and Seed Size. Asian Journal of Chemistry, 17 (1): 481489

Kandemir N., Yıldırım A. and Gunduz R., 2010. Determining the levels of genetic variation using SSR markers in three Turkish barley materials known as Tokak. Turk J. Agric. For., 34: 17-23

Kaydan D. ve Yağmur M., 2007. Van Ekolojik Koşullarında Bazı İki Sıralı Arpa Çeşitlerinin (Hordeum vulgare L. conv. distichon) Verim ve Verim Öğeleri Üzerine Bir Araştırma. Ankara Üniversitesi Ziraat Fakültesi Tarım Bilimleri Dergisi,13 (3): 269-278
Kenar D. ve Şehriali, S., 2001. Farklı ekim zamanlarının 2 ve 6 sıralı arpa çeşitlerinin verim ve verim öğeleri üzerine etkileri. Türkiye 4. Tarla Bitkileri Kongresi, s.177-182, Tekirdağ

Kutlu H. R., 2008. Yem değerlendirme ve analiz yöntemleri (Ders notu). Çukurova Üniversitesi Ziraat Fakültesi Zootekni Bölümü, ADANA

Kün E., 1988. Serin İklim Tahılları. Ders Kitabı, No: 299, A.Ü. Ziraat Fakültesi Yay:1032, Ankara

Marschner H., 1995. Mineral nutrition of higher plants, 2nd edn. London: Academic Press

Owen B. D., Sosulski F., Wu K. K. and Farmer M. J., 1977. Variation in mineral content of Saskatchewan feed grains. Con. J. Anim. Sci., 57: 679-687

Öztürk İ., Avcı R. and Kahraman, T., 2007. Trakya bölgesinde yetiştirilen bazı arpa (Hordeum vulgare $\mathrm{L}$ ) çeşitlerinin verim ve verim unsurları ile bazı kalite özelliklerinin belirlenmesi. U. Ü. Ziraat Fakültesi Dergisi, 21 (1): 59-68

Parzies H.K., Spoor W. and Ennos R.A., 2000. Genetic diversity of barley landrace accessions (Hordeum vulgare ssp. vulgare conserved for different lengths of time in ex situ gene banks, Heredity, 84: 476-486

Price H.A.,1962. RNA-synthesis zinc deficiency and the kinetics of growth. Plant Physiol, 37

Sadıç S., 1998. Bazı arpa çeşitlerinin Isparta şartlarında uyum yeteneklerinin belirlenmesi. Yüksek Lisans Tezi. Süleyman Demirel Üniversitesi. Fen Bilimleri Enstitüsü, Isparta

Sairam R. and Singh, S., 1989. N use efficiency, N assimilation and morphophysiological traits in barley. Rachis Barley and Wheat Newsletter, 9 (2): $26-28$

Sipahi H., Sayım İ., Ergün N. ve Çetin G., 2010. Maltık kalitesi yüksek arpa (Hordeum vulgare L.) çeşitlerinin geliştirilmesi. (Biyoteknoloji iş paketi: İkiye katlanmış haploid bitkilerin üretilmesi). Tübitak Projeleri

Sönmez F. ve Yılmaz, N., 2000. Azot ve fosforun arpa tanesinin bazı makro ve mikro besin maddesi içerikleri üzerine etkisi. Tarım Bilimleri Dergisi, 6 (2): 65-75

Stewart A., Nield H. and John, N., 1988. An Investigation of mineral content of barley grains and seedlings. Plant Physiol, 86: 9397

Turan i.., 2008. Kahramanmaraş koşullarında bazı buğday, arpa ve tritikale çeşitlerinin verim ve verim özelliklerinin belirlenmesi. Yüksek Lisans Tezi, Fen Bilimleri Enstitüsü/Tarla Bitkileri Ana Bilim Dalı, Kahramanmaraş 
Villacres E. and Rivadeneira M., 2005. Barley in Ecuador: production, grain quality for consumption and perspectives for improvement. Pages 127-137 in: Food Barley-Importance Uses and Local Knowledge: Proc. International Workshop on Food Barley Improvement, Jan. 2002. S. Grando and H. G. Macpherson, eds. ICARDA, Aleppo, Syria
Van Soest P. J. Robertson J. B. and Lewis B. A. 1991. Methods for dietary fiber, neutral detergent fiber, nonstarch polysaccharides in relation to animal nutrition. J. Dairy Sci., 74,3583-3597

Weltzien E. and Fiscbeck G., 1990. Performance and Variability of Local Barley Landraces in NearEastern Environments. Plant Breeding, 104, 58-67 